\title{
Yield and Economics of Pearlmillet (Pennisetum glaucum) as Influenced by Sowing Methods and Zinc Application under Rainfed Condition
}

\author{
A.K. Katiyar, U.D. Awathi, Shalender Pratap Singh, \\ Brajesh Prajapati* and Ashutosh Pandey \\ Department of Soil and Water Conservation CSAUAT Kanpur, India \\ *Corresponding author
}

\section{A B S T R A C T}

\begin{tabular}{|c|}
\hline Keywords \\
\hline $\begin{array}{l}\text { Pearlmillet, } \\
\text { Sowing methods, } \\
\text { Zinc levels, Yield, } \\
\text { Economics. }\end{array}$ \\
\hline Article Info \\
\hline $\begin{array}{l}\text { Accepted: } \\
\text { 26 May } 2017 \\
\text { Available Online: } \\
\text { 10 June } 2017\end{array}$ \\
\hline
\end{tabular}

A 2-year field experiment was conducted with 'Samrat-131' cultivar of pearlmillet (Pennisetum glaucum) having 4 sowing methods (uniform rows, paired rows, uniform rows followed by ridging and furrowing 20 DAS and criss-cross sowing) and 3 levels of zinc $(2.5,5.0$ and $7.5 \mathrm{~kg} \mathrm{Zn} / \mathrm{ha})$ during kharif 2011 and 2012 under rainfed condition. Uniform row sowing $(45 \mathrm{~cm})$ followed by ridging and furrowing recorded highest grain yield $(23.96 \mathrm{q} / \mathrm{ha})$, maximum water use efficiency $(4.99 \mathrm{~kg}$ grain/ $\mathrm{ha} \mathrm{mm})$ and earned highest net return (Rs. 5571/ha) with maximum B: C ratio (1.28) on mean basis of both year results. This grain yield was found 1.54, 2.07 and $3.91 \mathrm{q} /$ ha or $6.9,9.5$ and $19.5 \%$ higher than the yields obtained under paired row sowing, criss-cross sowing and uniform row sowing, respectively. Net return obtained with uniform rows followed by ridging and furrowing was found Rs. 615, 1747 and 2973/ha or 12.4, 45.7 and $114.4 \%$ higher than that with paired rows, criss-cross sowing and uniform rows, respectively. Zinc at $7.5 \mathrm{~kg} / \mathrm{ha}$ recorded highest values of grain yield $(24.15 \mathrm{q} / \mathrm{ha})$, water use efficiency $(4.91 \mathrm{~kg}$ grain/ha $\mathrm{mm}$ ), net return (Rs. 6195/ha) and B: C ratio (1.31). This grain yield was found 1.90 and $4.3 \mathrm{q} / \mathrm{ha}$ or 8.5 and $21.7 \%$ and net return Rs. 1761 and $4110 /$ ha or 39.7 and $197.1 \%$ of higher than lower levels of 5.0 and $2.5 \mathrm{~kg} \% \mathrm{Zn} / \mathrm{ha}$, respectively.

\section{Introduction}

Pearlmillet (Pennisetum glaucum) is an important millet crop of Uttar Pradesh grown mostly during kharif season under rainfed condition. It is efficient in its utilization of soil moisture and has a higher level of heat tolerance, thus considered a better crop for rainfed areas particularly in light textured and well drained soils. Those soils are lass retentive of soil moisture and generally poor in fertility level, therefore, crop productivity is low. Rain moisture conservation is most important concern in such areas. The balanced and optimum use of fertilizers is very important for good harvest of rainfed pearlmillet. Improved sowing methods like paired row soing and ridging and furrowing may be helpful increasing the availability of soil moisture for crop plants through better rain water conservation. In fertilization, brides $\mathrm{N}, \mathrm{P}$ and $\mathrm{K}$, minor elements may also play an important role in increasing crop productivity. Application of zinc has been retorted beneficial for rainfed pearlmillet (Sharma et al., 2008). It is helpful in the synthesis of IAA; essential for water uptake. Besides, zinc takes part in metabolism of plant as an 
activator of several enzymes and in turn may directly or indirectly effect the synthesis of carbohydrate and proteins (Arya and Singh, 2000). The present study was, therefore, undertaken to determine a suitable methods of sowing and proper dose of zinc application for increasing the productivity of rainfed pearlmillet crop.

\section{Materials and Methods}

Field experiment were conducted during kharif 2011 and 2012 at soil conservation and Water Management Research of C.S. Azad University of Agriculture and Technology, Kanpur. The soil of experimental field was sandy loam in texture and slightly alkaline in nature $(\mathrm{pH}$ 7.8) with average fertility. Treatments consisted of four sowing methods (uniform sowing, paired row sowing, uniform sowing followed by ridging and furrowing at 20 days after sowing and criss-cross sowing) and three levels of zinc application (2.5, 5.0 and $7.5 \mathrm{~kg} \mathrm{Zn/ha).} \mathrm{A} \mathrm{factorial} \mathrm{randomized}$ block design with three replications was used.

The crop was sown at optimum soil moisture on 2.8.2011 and 28.07.2012 in furrows behind country plough using $5 \mathrm{~kg} / \mathrm{ha}$ seed. In uniform and criss-cross sowing, furrow spacing was kept $45 \mathrm{~cm}$ uniform while paired rows were sown at 30/60 $\mathrm{cm}$ spacing. A uniform dose of $40 \mathrm{~kg} \mathrm{~N}+40 \mathrm{~kg} \mathrm{P}_{2} \mathrm{O}_{5}+40 \mathrm{~kg} \quad \mathrm{~K}_{2} \mathrm{O} / \mathrm{ha}$ was applied at proper soil moisture in all treatment plots. Zinc was applied through zinc sulphate. It was applied as per treatment at sowing with fertilizers application.

Thinning of extra plants was done after 15 days of germination in all plots. One hand weeding was done after 20 days of sowing. In the treatment plots of ridging and furrowing, ridge was used to form ridges on plant rows at 20 days after sowing. The experimental crop received total rainfall of $356.6 \mathrm{~mm}$ and 274.7 mm during its life cycle of 2011 and 2012, respectively.

\section{Results and Discussion}

\section{Effect of sowing methods}

Uniform sowing followed by ridging and furrowing recorded highest values of plant height, tillers/plant, stem girth, spike length and weight, 1000-grain weight and harvest index. It was followed by paired row sowing while uniform sowing alone recorded lowest values of above mentioned growth and yield attributes during both years (Table 1). It might be attributed to extra advantage of ridging and furrowing which perhaps conserved more soil moisture in furrows for plant use throughout life span of crop. Maximum water use efficiency under this treatment of ridging and furrowing also support this reason. Higher growth and yield attributes under paired row sowing than other treatments may be explained that both side rows of pair availed the side space properly for better growth of plants and roots extension which helped in absorbing more plant nutrients. These results support the findings of Jat and Gautam (2000).

Grain and stover yields recorded significantly highest under uniform sowing with ridging and furrowing followed by paired row sowing while the uniform sowing alone produced significantly lowest yields (Table 2). On the basis of 2-years average, uniform sowing with ridging and furrowing produced $1.54 \mathrm{q} / \mathrm{ha}$ or $6.87 \%, 2.07 \mathrm{q} / \mathrm{ha}$ or $9.46 \%$ and $3.91 \mathrm{q} / \mathrm{ha}$ or $19.50 \%$ higher grain yield than the sowing methods of paired row sowing, criss-cross sowing and uniform sowing alone, respectively.

Such higher crop yields might be attributed to different growth characters and yield attributes which also behaved similarly under different sowing methods. Thus, cumulative effect of growth and yield attributes might has increased the crop yields under uniform sowing with ridging and furrowing method. 
Table.1 Effect of sowing methods and zinc levels on growth and yield contributing characters of rainfed pearlmillet

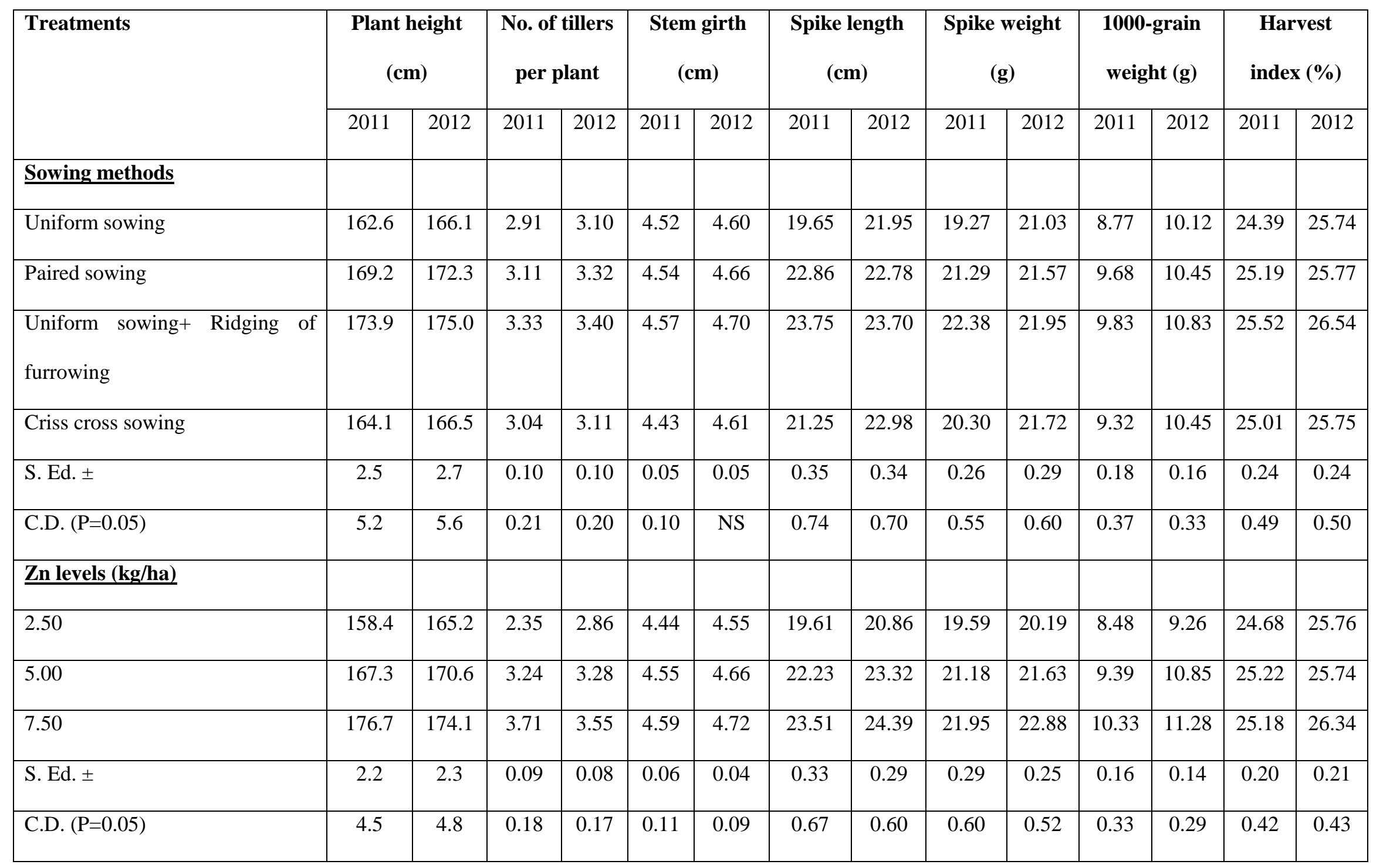




\section{Int.J.Curr.Microbiol.App.Sci (2017) 6(6): 2958-2963}

Table.2 Effect of sowing methods and zinc levels on crop yield, water use and economics of rainfed pearlmillet

\begin{tabular}{|c|c|c|c|c|c|c|c|c|c|c|c|c|c|c|}
\hline \multirow[t]{3}{*}{ Treatments } & \multicolumn{4}{|c|}{ Crop yield (q/ha) } & \multicolumn{4}{|c|}{ Water use by crop } & \multicolumn{6}{|c|}{ Economics } \\
\hline & \multicolumn{2}{|c|}{ Grain yield } & \multicolumn{2}{|c|}{ Stover yield } & \multicolumn{2}{|c|}{$\begin{array}{l}\text { Total water use } \\
\qquad(\mathrm{mm})\end{array}$} & \multicolumn{2}{|c|}{$\begin{array}{l}\text { Water use } \\
\text { efficiency kg } \\
\text { grain/ha mm }\end{array}$} & \multicolumn{2}{|c|}{$\begin{array}{l}\text { Gross return } \\
\text { (Rs./ha) }\end{array}$} & \multicolumn{2}{|c|}{$\begin{array}{l}\text { Net return } \\
\text { (Rs./ha) }\end{array}$} & \multicolumn{2}{|c|}{$\mathrm{B}: \mathrm{C}$ ratio } \\
\hline & 2011 & 2012 & 2011 & 2012 & 2011 & 2012 & 2011 & 2012 & 2011 & 2012 & 2011 & 2012 & 2011 & 2012 \\
\hline \multicolumn{15}{|l|}{$\underline{\text { Sowing methods }}$} \\
\hline Uniform sowing & 18.51 & 21.58 & 57.32 & 62.15 & 482.5 & 485.1 & 3.84 & 4.00 & $\begin{array}{c}2053 \\
7\end{array}$ & 23479 & 1127 & 4069 & 1.06 & 1.21 \\
\hline Paired sowing & 21.86 & 22.98 & 64.87 & 66.20 & 478.5 & 481.6 & 4.57 & 4.64 & $\begin{array}{c}2397 \\
5\end{array}$ & 25004 & 4441 & 5471 & 1.23 & 1.28 \\
\hline $\begin{array}{llll}\text { Uniform } & \text { sowing+ } & \text { Ridging } & \text { of } \\
\text { furrowing } & & & \\
& & & \end{array}$ & 23.15 & 24.77 & 67.53 & 68.50 & 478.2 & 481.0 & 4.84 & 5.13 & $\begin{array}{c}2527 \\
6\end{array}$ & 26666 & 4876 & 6266 & 1.24 & 1.31 \\
\hline Criss cross sowing & 20.75 & 23.02 & 62.14 & 66.38 & 481.4 & 484.8 & 4.31 & 4.51 & $\begin{array}{c}2281 \\
6\end{array}$ & 25054 & 2705 & 4943 & 1.13 & 1.25 \\
\hline S. Ed. \pm & 0.47 & 0.41 & 2.06 & 0.91 & - & - & - & - & - & - & - & - & - & - \\
\hline C.D. $(\mathrm{P}=0.05)$ & 0.98 & 0.86 & 4.26 & 1.89 & - & - & - & - & - & - & - & - & - & - \\
\hline \multicolumn{15}{|c|}{$\underline{\text { Zn levels (kg/ha) }}$} \\
\hline 2.50 & 18.33 & 21.35 & 55.86 & 61.45 & 478.9 & 482.1 & 3.83 & 4.01 & $\begin{array}{c}2024 \\
5\end{array}$ & 23225 & 595 & 3575 & 1.03 & 1.18 \\
\hline 5.00 & 21.47 & 23.03 & 63.55 & 66.39 & 483.4 & 486.7 & 4.44 & 4.72 & $\begin{array}{c}2353 \\
2\end{array}$ & 25063 & 3668 & 5199 & 1.18 & 1.26 \\
\hline 7.50 & 23.41 & 24.89 & 69.49 & 69.59 & 484.8 & 488.1 & 4.83 & 4.99 & $\begin{array}{c}2567 \\
5\end{array}$ & 26871 & 5597 & 6793 & 1.28 & 1.34 \\
\hline S. Ed. \pm & 0.41 & 0.36 & 1.78 & 0.79 & - & - & - & - & - & - & - & - & - & - \\
\hline C.D. $(\mathrm{P}=0.05)$ & 0.85 & 0.74 & 3.68 & 1.64 & - & - & - & - & - & - & - & - & - & - \\
\hline
\end{tabular}


These results confirm the findings of Yadav and Varshney (2005). Water use efficiency was computed highest under sowing method of uniform sowing with ridging and furrowing closely followed by paired row sowing (Table 2).

It was found mainly attributed to grain yield because total water use by the crop was almost similar under both above sowing methods.

Gross and net return and $\mathrm{B}: \mathrm{C}$ ratio from pearlmillet crop were obtained maximum under uniform sowing with ridging and furrowing followed by paired row sowing while minimum were obtained under uniform sowing alone (Table 2). On an average of 2years data, the method of uniform sowing with ridging and furrowing earned highest of Rs. 5571/ha net return followed by paired row sowing (Rs. 4956/ha), criss-cross sowing (Rs. 3824/ha) and uniform sowing alone (Rs. 2598/ha). Thus, uniform sowing with ridging and furrowing earned Rs. 615/ha or $12.4 \%$, Rs. $1747 /$ ha or $45.7 \%$ and Rs. $2973 /$ ha or $114.4 \%$ more net return than the methods of paired sowing, criss-cross sowing and uniform sowing alone, respectively. Gross return values are attributed to grain and stover yields while net return values are affected by both gross return and total cost of crop cultivation.

\section{Effect of zinc levels}

Increasing levels of zinc application increased growth characters (plant height, tillers/plant, stem girth) and yield attributes viz. spike length, spike weight, 1000-grain weight, harvest index (Table 1) and grains and stover yields (Table 2) significantly with up to highest level of $7.5 \mathrm{~kg} \mathrm{Zn/ha} \mathrm{during} \mathrm{both}$ years. On mean basis of 2-years data, the application of $7.5 \mathrm{~kg} \mathrm{Zn/ha} \mathrm{produced} \mathrm{highest}$ of $24.15 \mathrm{q} / \mathrm{ha}$ grain and $69.54 \mathrm{q} / \mathrm{ha}$ stover yields, which were found 1.90 and $4.31 \mathrm{q} / \mathrm{ha}$ or 8.5 and $21.7 \%$ more grain yield and, 4.57 and $10.28 \mathrm{q} / \mathrm{ha}$ or 7.0 and $18.5 \%$ more stover yield than 5.0 and $2.5 \mathrm{~kg} \mathrm{Zn} / \mathrm{ha}$ levels, respectively. Significant growth and yield response to higher levels of zinc application might be attributed to increased availability and uptake of zinc by crop plants which takes part in metabolism of plant as an activator of several enzymes and in turn may directly or indirectly affect the synthesis of carbohydrate and protein (Aryan d Singh, 2000). Table water use and water-use efficiency also increased with increasing zinc application (Table 2). It might be attributed to improved shoot and root growth of plants and significant increased grain yield.

Economic parameters viz. gross return, net return and benefit: cost ratio increased with zinc application and maximized at highest level of $7.5 \mathrm{~kg} \mathrm{Zn} / \mathrm{ha}$ during both years. It might be attributed to increased grain and stover yields with zinc application. The value of increased yield was much more than the cost of zinc application which increased the net return and $\mathrm{B}$ : $\mathrm{C}$ ratio. On the basis of 2year results, $7.5 \mathrm{~kg} \mathrm{Zn} / \mathrm{ha}$ earned maximum of Rs. 6195/ha net return which was found Rs. 1761 and Rs. 4110/ha or 39.7 and $197.1 \%$ more than the net returns obtained at 5.0 and $2.5 \mathrm{~kg} \mathrm{Zn/ha,} \mathrm{respectively.} \mathrm{These} \mathrm{results}$ corroborate to the findings of Jakhar et al., (2006) and Sharma et al., (2008).

Interaction effect between sowing methods of pearlmillet and application of zinc levels was not found significant in any crop character studied. However, the combination of both best factors i.e. uniform sowing with ridging and furrowing and application of $7.5 \mathrm{~kg}$ zinc/ha has given highest crop yields and earned maximum net return from rainfed pearlmillet cultivation in control Uttar Pradesh condition. 


\section{References}

Arya, K.C. and Singh, S.N. (2000). Effect of different levels of phosphorus and zinc on yield and nutrients uptake of maize (Zea mays) with and without irrigation. Indian Journal of Agronomy, 45 (4): 717-721.

Jakhar, S.R., Singh, M. and Balai, C.M. (2006). Effect of farmyard manure, phosphorus and zinc levels on growth, yield, quality and economics of pearlmillet. (Pennisetum glaucum). Indian Journal of Agricultural cienc, 76 (1) : 58-61.

Jat, M.L. and Gautam, R.C. (2000). Impact of summer ploughing and in-site moisture conservation practices on growth and yield of pearlmillet. Indian Journal of Agronomy, 45 (4): 722-727.

Sharma, O.P., Yadav, G.L. and Ram Pratap (2008). Effect of integrated nutrient management under varying levels of zinc on pearlmillet yield. Annuals of Arid Zone, 47 (2): 197-199.

Yadav, S.T. and Varshney, M.C. (2005). Influence of sowing dates and sowing methods on growth and yield of pearlmillet. Journal of Agrometeorology, 7 (2): 319-321.

\section{How to cite this article:}

Katiyar, A.K., U.D. Awathi, Shalender Pratap Singh, Brajesh Prajapati and Ashutosh Pandey. 2017. Yield and Economics of Pearlmillet (Pennisetum glaucum) as Influenced by Sowing Methods and Zinc Application under Rainfed Condition. Int.J.Curr.Microbiol.App.Sci. 6(6): 2958-2963. doi: https://doi.org/10.20546/ijcmas.2017.606.352 